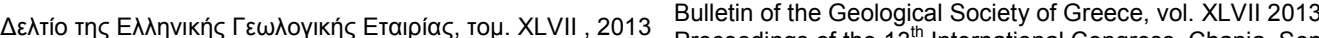

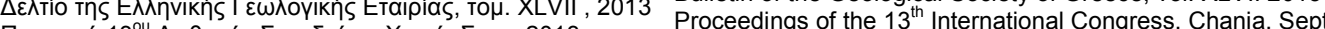

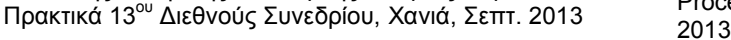

\title{
MICROTREMOR HVSR STUDY OF SITE EFFECTS IN THE URBAN AREA OF THE TOWN OF MYTILENE, LESVOS (GREECE) - PRELIMINARY RESULTS
}

\section{Bouranta E. ${ }^{1}$, Vallianatos F. ${ }^{2}$, Hatzopoulos J.N. ${ }^{1}$, Papadopoulos I. $^{2}$ and Gaganis P. ${ }^{1}$}

\author{
${ }^{1}$ University of Aegean, Department of the Environment University Hill, Mytilene, Greece \\ ${ }^{2}$ Laboratory of Geophysics \& Seismology, Technological Educational Institute of Crete, Chania, \\ Crete, Greece
}

\begin{abstract}
Mytilene is the capital of Lesvos, the eighth largest island in the Mediterranean Sea and the largest in the North Aegean. The region of North Aegean is a geotectonically complex area, because its geodynamic status is directly affected by the North Anatolian Fault Zone. In the present paper, microtremor data have been analyzed for the city of Mytilene using Nakamura technique of Horizontal to Vertical Spectral Ratio (HVSR) to ascertain the structure in terms of the predominant frequency. 100 microtremor measurements have been performed in the city of Mytilene. At each point of microtremor measurement, the natural frequency and amplification factor have been determined. The predominant frequency varies from $0.4 \mathrm{~Hz}$ to $6.6 \mathrm{~Hz}$. The amplification factor in 0.4-8.07 range has been obtained from the HVSR analysis. The results are presented in terms of maps, including the spatial variability of the predominant frequency and developed GIS database. The results of this study make it clear that the characteristics of microtremors depend on the type of soil deposits. Key words: Nakamura method, amplification factor, natural frequency, GIS
\end{abstract}

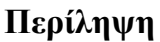

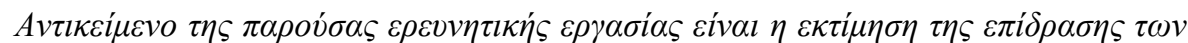

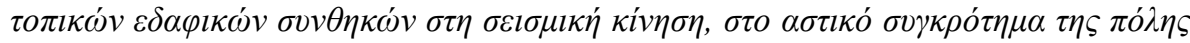

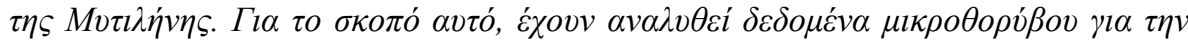

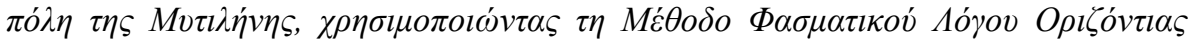

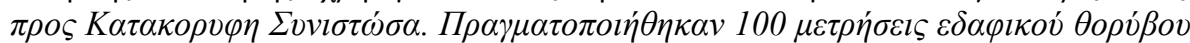

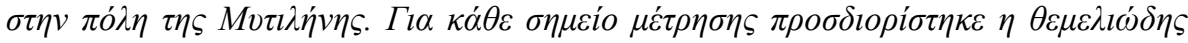

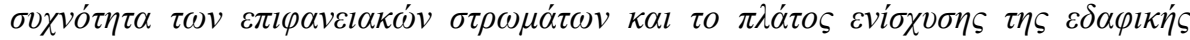

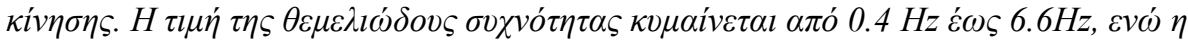

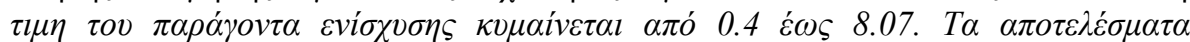

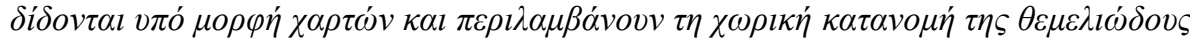

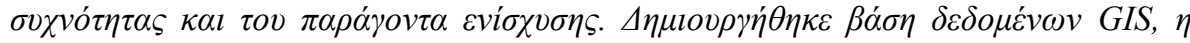

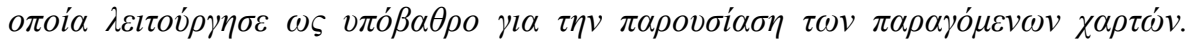

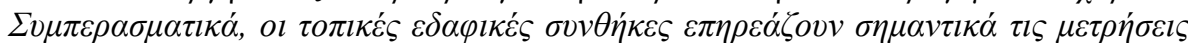

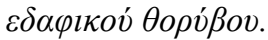

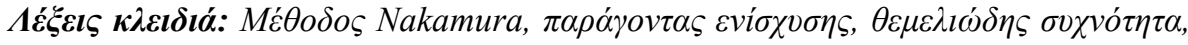
Г. ...П.

$\underline{\text { XLVII, No } 3 \text { - } 1081}$ 


\section{Introduction}

The seismic action has considerably negative repercussions in the material and technical infrastructure and by extension in the social and economic life. In the economic cost that involves the alleviation of affected regions and the reset of damage should be added also the loss of markets (products and services) in a continuously more competitive economic environment at international level. This fact makes the need for mitigation of repercussions of seismic destructions imperative.

The distribution of earthquake damage is directly dependent on local site conditions. In the present paper we have attempted to study the site effects and the site ground response in the case of an earthquake in the urban area of Mytilene (Lesvos, Greece). This area is exposed to seismic hazard because is a very active area with high seismicity. The Nakamura technique has been adopted for the microtremor measurements analysis (HVSR) to determine the predominant frequency of the soils in this area.

The Nakamura technique has gained much popularity over the past years because it is inexpensive method and can be applied to regions of low seismicity. Also, it requires only a single station. One drawback of the HVSR technique is the theory on which it is based. There is a disagreement among various researchers on the nature of the microtremor as there is no established theory concerning the kind of wave motions the microtremor survey provides (Bard, 1999).

Although the specific mechanism causing wave amplification can vary from site to site, several studies suggest that ambient noise, or weak motions, can be used to identify areas that might amplify earthquake ground motions in advance of earthquake occurrence (Nakamura 1989, 1997). In this paper, we investigate the use of microtremors, or ambient noise, using horizontal-to-vertical spectral ratios (HVSRs) to study potential site effects on seismic ground motions in the urban area of the town of Mytilene. We determine predominant frequencies and relative amplification derived from the microtremor measurements, and we interpret these results in the context of geotechnical studies and geological maps. The spatial locations of all measurements and their analysis are managed by a GIS data base which has been designed to accommodate this study.

\section{Materials and Methods}

\subsection{Geological Characteristics and Seismicity of the Study Area}

Lesvos is the eighth largest island in the Mediterranean Sea and the third largest island of the Greek Islands, with 1.632 square kilometres in extent. It is located in the northeastern Aegean Sea. The city of Mytilene is the capital of the island of Lesvos and of the Prefecture of Lesvos.

Several studies carried out by Hecht (1972, 1974a,b), Pe-Piper (1978), Katsikatsos et al. (1982, 1986), and Pe-Piper and Piper (1993) described the geology and provided the geological maps of Lesvos Island (Figure 1). The geology can be summarized as a basement composed of Alpidic and pre-Alpidic metamorphic rocks which were covered later by post-Alpine formations, mainly Miocene volcanic rocks and Neogene marine and lacustrine deposits. (Soulakellis et al., 2006).

The North Aegean region is a geotectonically complex area. Its geodynamic status is directly affected by the North Anatolian Fault Zone, is westward continuation in the Aegean Sea, known as the North Aegean Trough and the West Anatolia Graben System in Asia Minor with significant historical seismicity (Papazachos and Papazachou, 1997). The island belongs in the old volcanic arc that acted at the Middle Miocene 15-19 million years ago. This area is characterized by high seismicity hazard and it had been affected many times in the past by powerful devastating earthquakes.

Instrumental records and historic sources clearly indicate the high seismicity of Lesvos Island. Among the destructive earthquakes of the island, the most devastating was the 1867 event (estimated intensity IX to X in Mercalli scale).

XLVII, No 3 - 1082 


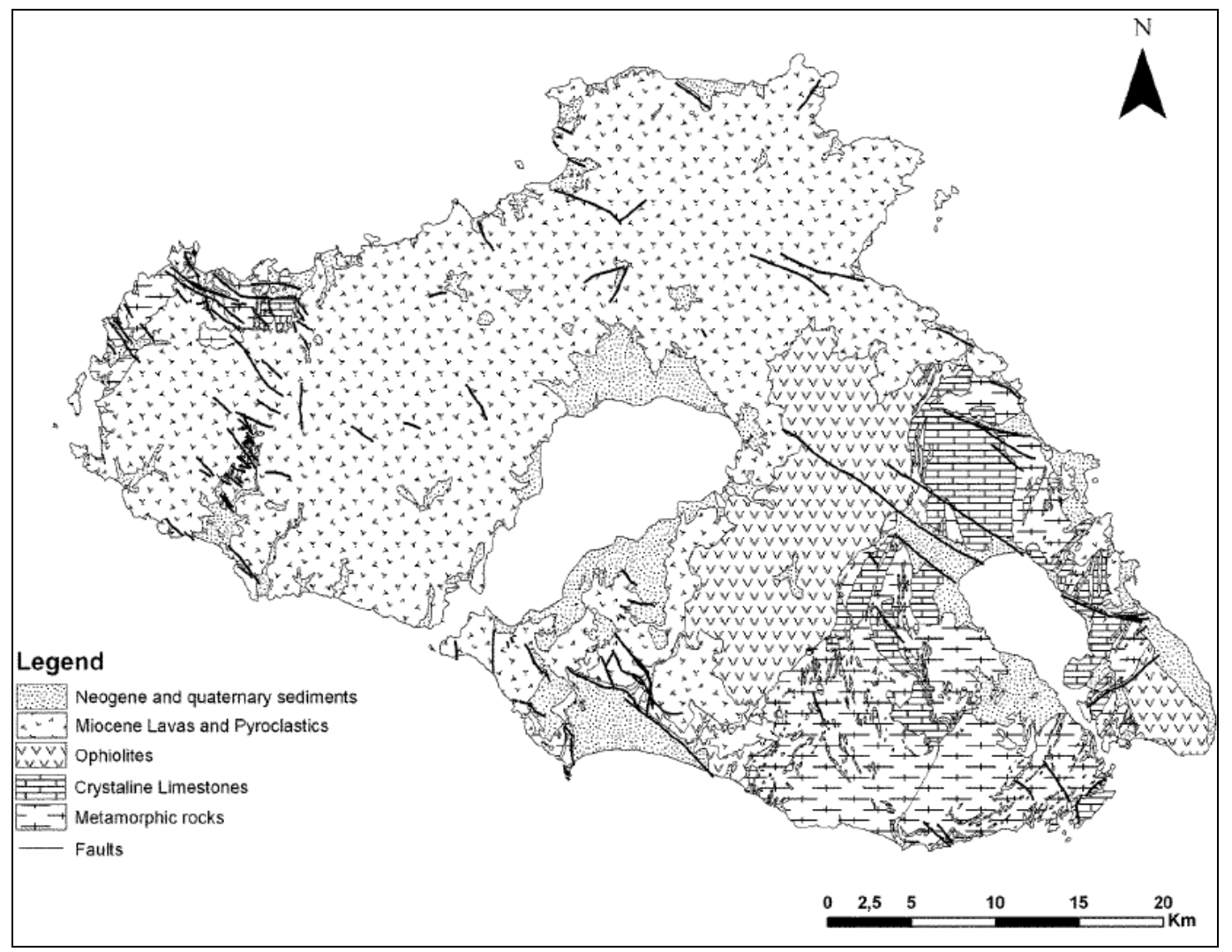

Figure 1- Simplified Geological Map of Lesvos Island (from Hecht, 1971-1974).

Mytilene is the capital of Lesvos and located at the eastern part of the island. The altitude fluctuates from 0 to $100 \mathrm{~m}$ and it has a smooth relief.

\subsection{Methodology}

In the present paper microtremor measurements have been conducted in order to study the site effects and the site ground response in case of an earthquake in the urban area of Mytilene. For this reason the Horizontal-to-Vertical Spectral Ratio (HVSR) technique has been applied on ambient noise measurements (Nakamura's technique). This method is particularly widespread the last years and several scientific studies that are referred to this have been published internationally. (Bonnefoy - Claudet et al. 2006a, 2006b; Field and Jacob, 1993; Gosar, 2007).

Although the microtremor method is well established, its ability to predict wave amplification and predominant frequency of strong motion has been debated. However, still a topic of debate, the use of microtremor is very attractive because it is fast and low-cost technique. Because of its sensitivity to spatial variations of near surface geology, the method is particularly attractive in urban areas.

This method utilizes the microtremor data from digital highly sensitive wideband seismographs with high dynamic range (24 bits). It aims to determine the fundamental frequency of local ground resonance and the empirical transfer function. Moreover, this method can be used as a powerful tool to estimate the thickness of soft-cover layers (Seht and Wohlenberg, 1999).

Microtremor measurements have been performed in the urban area of town of Mytilene. With the term "microtremors" we define Earth' s surface vibration caused by daily human activities such as machinery movement in factories, motor cars, people walking and natural phenomena (flow of

$\underline{\text { XLVII, No } 3-1083}$ 
water in rivers, rain, wind, variation in atmospheric pressure and ocean waves). The microtremor record, as each seismic record, is a signal that gives information related to: a) seismic source mechanism, b) attenuation path and c) site conditions of the recording station.

Generally, microtremor data has been used to estimate fundamental frequency of a site in order to identify the site's response during an earthquake. This technique uses the spectral ratio between horizontal and vertical components (H/V ratio) of microtremors (Nogoshi and Igarashi, 1971; Nakamura, 1989). It is known as Nakamura's technique or HVSR method and has been applied in the present paper.

Afterwards, the microtremor records have been processed according to the steps proposed by Mucciarelli (1998) and Duval et al. (2004). In this way, the experimental Horizontal-to-Vertical Spectral Ratio and the fundamental frequency are calculated. Finally, a predominant frequency map is generated which reflects the fundamental characteristics of possible site effects. (Yamanaka et al., 1994; Duval et al., 1995; Field, 1996; Fäh et al., 1997; Ibs-von Seht and Wohlenberg, 1999; Jiménez et al., 2000; Delgado et al., 2000a; Delgado et al., 2000b; Alfaro et al., 2001; Navarro et al., 2001; Duval et al., 2001a,b; Woolery and Street, 2002; Hloupis et al., 2005; Vallianatos and Hloupis, 2008; Sarris et al., 2010; Moisidi et al., 2012; Moisidi et al., 2013).

\subsection{Data Acquisition and Analysis}

The acquisition of data has been performed using the CITYSHARK II recorder connected to the Lennartz Le3D/5s velocimeter. The CITYSHARK system was developed by the French Institute for Research and Development (IRD) and a local French company (LEAS) for specifically ambient vibration measurements (Chatelain et al., 2000).

Ambient noise measurements have been performed in the city of Mytilene from May 2012 to February 2013. 100 measurements of ambient noise have been conducted throughout the city. The measurements have been carried out from Monday to Friday at hours 23:00-02:30. A global Positioning System (GPS) module localizes the spatial position of each point of measurement (Hatzopoulos, 2008). The sampling rate was set to $200 \mathrm{~Hz}$ and the duration of recording 30 minutes. These data are acquired according to guidelines proposed by Duval et al., 2004. The sites of microtremor recordings were selected to cover all different geological formations of the area. Though the HVSR technique is independent of the sources, there are certain criteria that were taken into consideration. Sites very close to heavy traffics were avoided for nearby strong sources that can distort the recordings for the proper recording of ambient noise. Some of these measurements have been repeated to minimize artificial noises due to traffic human activities. Figure 2 shows the locations of measured points in the urban area of town of Mytilene.

The H/V ratios are calculated using the GEOPSY software (www.geopsy.org), for the frequency range 0.2 to $20 \mathrm{~Hz}$, using 40s time windows and removing time windows contaminates by transients. The interpretation of the $\mathrm{H} / \mathrm{V}$ curve has been carried out conformably to international consensus criteria (Duval et al., 2004). The Fourier amplitude spectra of each selected window are computed. The HVSR relation of Nakamura (1989) is applied for each individual window and the final predominant frequency is obtained.

\section{Results and Discussion}

Microtremor measurements have been performed in the urban area of the town of Mytilene for a preliminary evaluation of site response. The signals recorded have been analyzed for horizontal to the vertical (H/V) sprectral ratio. The scrutiny of $\mathrm{H} / \mathrm{V}$ data set allows us to keep only reliable data for mapping resonance frequencies in the city of Mytilene.

The Figure 3 shows the results obtained through the analysis of microtremor. The dotted curves represent the upper and lower bound of 1 standard deviation around the mean spectral ratio,

$\underline{\text { XLVII, No } 3-1084}$ 


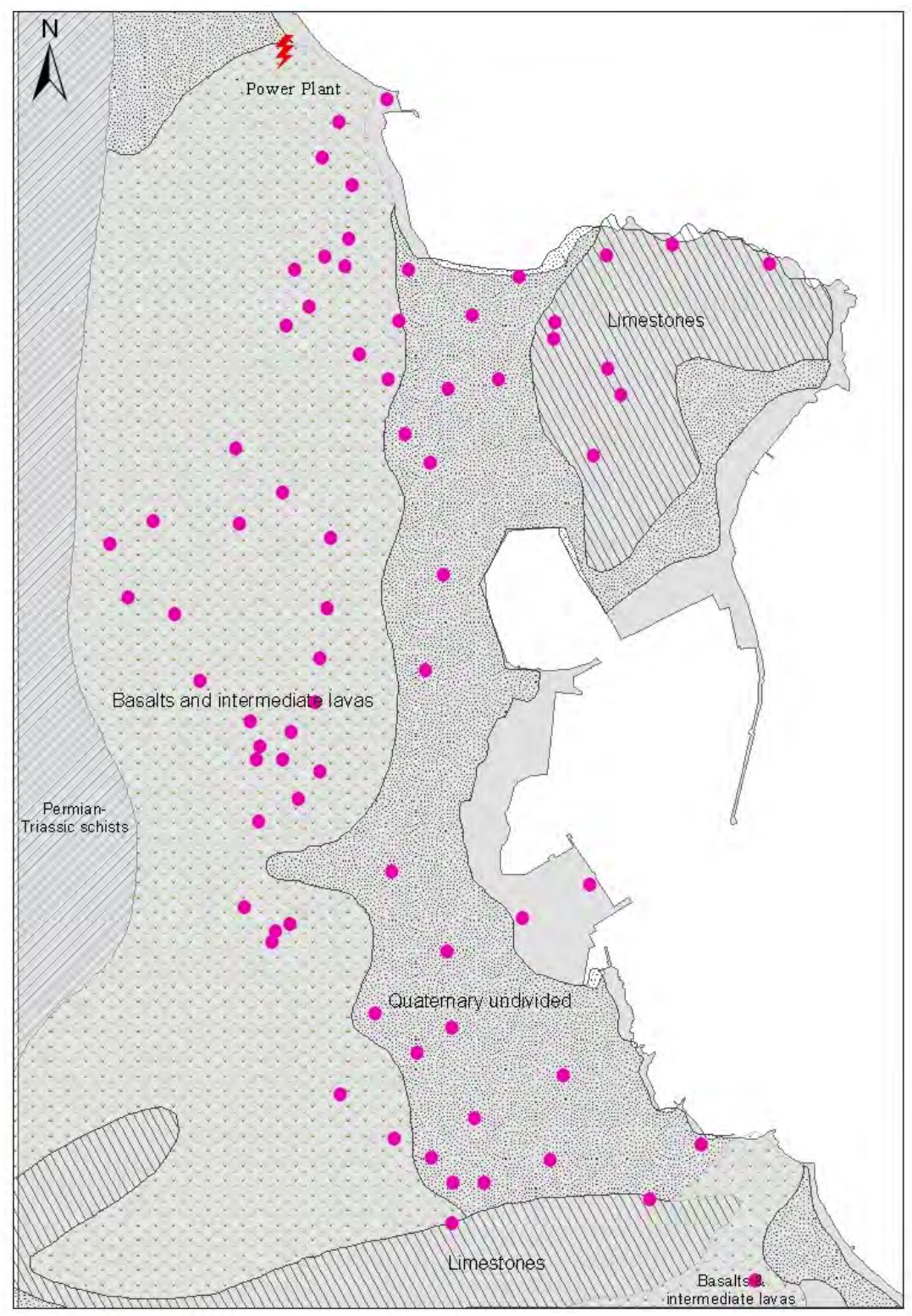

Figure 2 - Position map of microtremor measurements in the urban area of Mytilene.

respectively. Grey vertical bars show the selected H/V peak. The width of the vertical bars denotes the range of the peak frequency.

In order to represent the spatial distribution of the predominant frequency over the urban area of the town of Mytilene, interpolation between the microtremor positions has carried out using the geostatistical technique of nearest neighbour. Figure 4 shows the map of predominant frequency obtained from HVSR technique for the town of Mytilene. Moreover, using the same method of interpolation, the maximum amplification has been determined. Figure 5 represents the amplification factors of the predominant frequencies based on the $\mathrm{H} / \mathrm{V}$ of the microtremors in investigation sites. The generated maps are managed through a properly developed GIS database (Hatzopoulos, 2008), and are elaborated in laboratory of Remote Sensing and GIS (Department of Environmental Studies, University of the Aegean). 


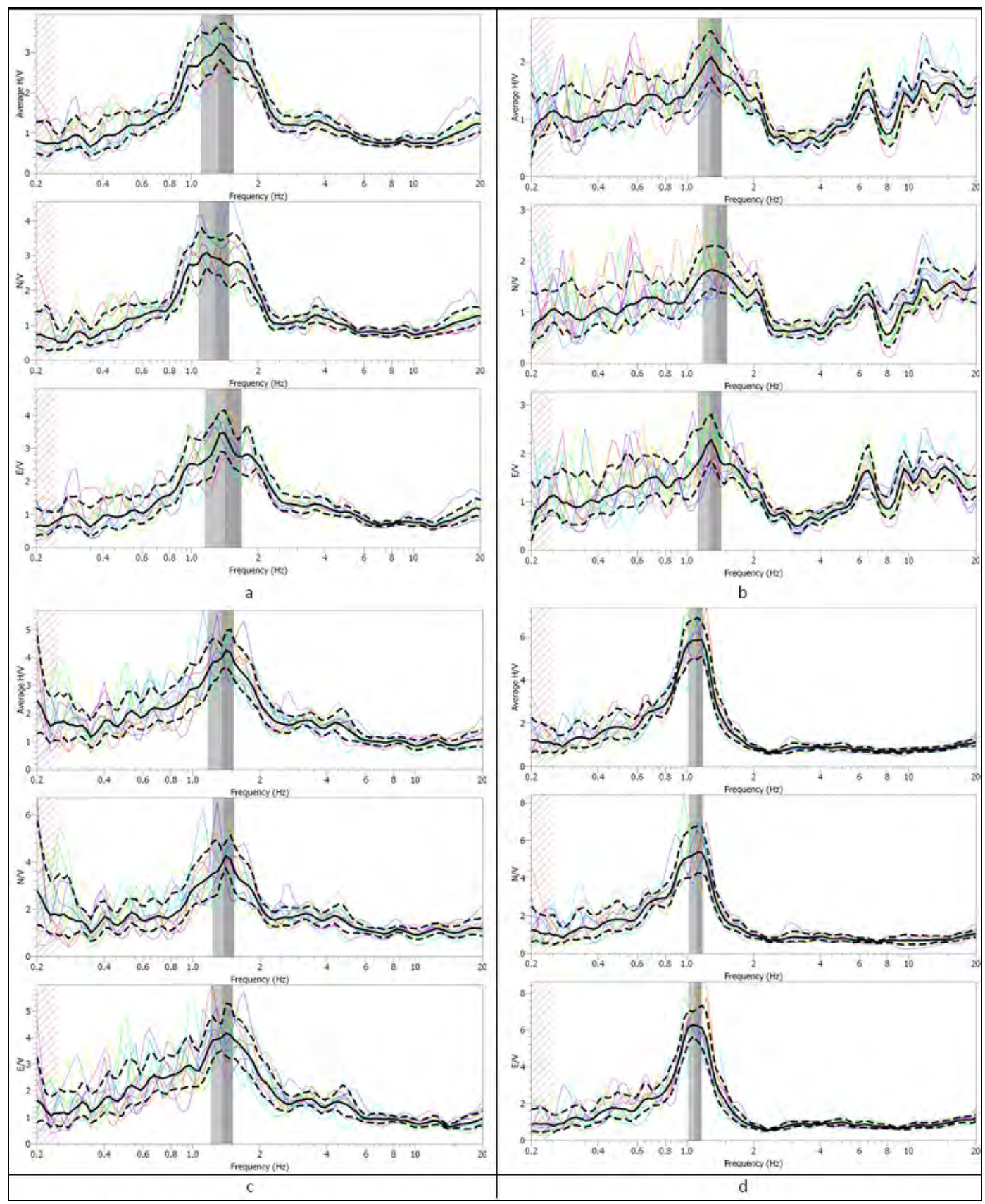

Figure 3 - Responses in sites 2, 11, 40, 89 as presented in Figure 4, 5.

The predominant frequencies ranged from 0.4 to $6.6 \mathrm{~Hz}$. The main reason for such a wide range of results arises from the large differences in the near- surface geological conditions of the region. It is worth noting that there were some of sharp peaks due to an industrial origin (power plant). These peaks have been excluded from the results, and the second peak of natural origin has taken instead. The amplification factor in investigation sites ranges from 0.4 to 8.07.

Consequently, the frequency and amplification distribution maps reflect the geology of the region. The results obtained in the present study can be extended for the seismic hazard studies. 


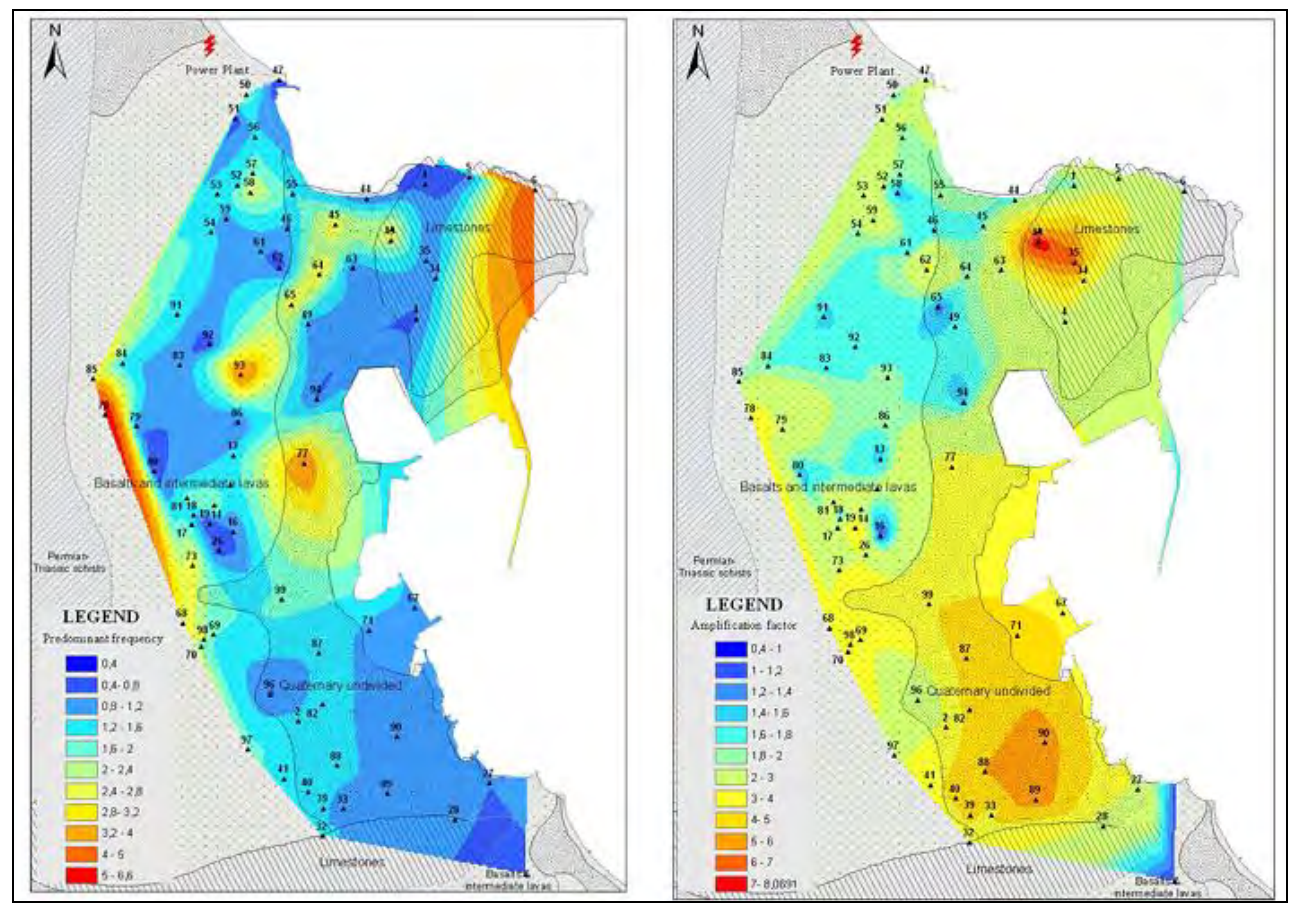

Figure 4 - Map of predominant frequency obtained from HVSR technique for the town of Mytilene.

Figure 5 - Map of the $\mathrm{H} / \mathrm{V}$ amplitude at fundamental frequencies for the town of Mytilene.

\section{Conclusions}

The microtremor records for the urban area of the town of Mytilene are analyzed for 100 positions. An attempt has been made to interpret variations of microtremor $\mathrm{H} / \mathrm{V}$ spectral ratios in terms of the local site geology. The main conclusions can be summarized as follows:

The distribution of predominant frequency is relative uniform, ranging from $0.4-6.6 \mathrm{~Hz}$, with the frequency value associated with the topographic pattern. Local high observed values are due to the ground surface geology. The amplification factor is ranging from 0.4 to 8.07. Amplification factor values lower than 1.2 are associated with areas where the bedrock appears at the ground surface. In these areas, ground shaking is not amplified. However, some high amplification factor values on NE part located on the limestone owing to possible anthropogenic noise and should be checked.

According to the observations and analysis presented earlier, the characteristics of microtremors are primarily dependent on the type of soils. As a further step, it would be recommendable to improve the spatial distribution of predominant frequency and amplification factor in Quaternary soils through a denser grid of microtremor measurements. Moreover, in the next stage of this research, a comparison of microtremors with the respective earthquake characteristics can be very beneficial and applicable in engineering.

The application of HVSR technique on microtremor measurements in the town of Mytilene showed encouraging results with regard to method potential and applicability. This method is proved very time and cost effective, and easy to implement.

The characteristics of microtremors are found to be mainly dependent on the type of soil deposits. Therefore, the $\mathrm{H} / \mathrm{V}$ microtremor spectral ratios technique may also represent valuable tool for soil type evaluation in addition to providing a valuable input in urban seismic microzonation and in seismic hazard mitigation. 


\section{Acknowledgments}

Bouranta Evangelia is supported by the Greek State Scholarships Foundation (IKY).

\section{References}

Alfaro A., Pujades L. G., Goula X., Susagna T., Navarro M., Sanchez J. and Canas A. 2001. Preliminary map of soil's predominant periods in Barcelona using Microtremors, Pure Appl. Geophys., 158,. 2499-2511.

Bard P. Y. 1999. Microtremor measurements: a tool for site effect estimation? Proc. of $2^{\text {nd }}$ International Symposium on the Effect of Surface Geology on Seismic Motion, Yocohama, Japan, 1251-1279.

Bonnefoy-Claudet S., Cornou C., Bard P.-Y. Cotton F., Moczo P., Kristek J. and Fäh D. 2006a. $\mathrm{H} / \mathrm{V}$ ratio: a tool for site effects evaluation. Results from 1-D noise simulations, Geophys. $J$. Int., 167, 827-837.

Bonnefoy-Claudet S., Cotton F. and Bard P.-Y. 2006b. The nature of noise wavefield and its applications for site effects studies, A literature review, Earth.-Sci. Rev., 79, 205-227.

Chatelain J. L., Guéguen P., Guillier B., Fréchet J., Bondoux F., Serrault J., Sulpice P. and Neuville J.M. 2000. CityShark: A user-friendly instrument dedicated to ambient noise (microtremor) recording for site and building response studies, Seismological Research Letters, Vol. 71(6), 698-703.

Delgado J., Lopez Casado C., Giner J., Estevez A., Cuenca A. And Molina S. 2000a. Microtremors as a Geophysical Exploration Tool: Application and Limitations, Pure and Applied Geophysics, 158, 2525-2541.

Delgado J., Lopez Casado C., Estevez A., Giner J., Cuenca A. and Molina S. 2000b. Mapping softsoils in the Segura river valley (SE Spain) a case study of microtremors as a e xploration tool, J. Appl. Geophys., 42, 19-32.

Duval A.-M., Bard P.-Y., LeBrun B., Lacave-Lacher C., Riepl J. and Hatzfeld D. 2001-b. H/V technique for site response analysis. Synthesis of data from various surveys. Boull. Geof. Teor. Appl., 42, 267-281.

Duval A.-M., Bard P.-Y., Meneroud J.-P., and Vidal S. 1995. Usefulness of microtremor measurements for site effects, Proc. of $10^{\text {th }}$ European Confer., Proc. of Earthquake Engineering, Vienna, Austria, 521-528.

Duval A.-M., Vidal S., Meneroud J.-P., Singer A., DeSantis F., Ramos C., Romero G., Rodriguez R., Pernia A., Reyes N. and Griman C. 2001-a. Site effect determination with Microtremors, Pure Appl. Geophys., 158, Caracas, Venezuela, 2513-2523.

Duval A.-M., Chatelain J.-L., Guillier B. and the SESAME WP02 team. 2004. Influence of experimental conditions on $\mathrm{H} / \mathrm{V}$ determination using ambient vibrations (noise), $13^{\text {th }}$ World Conf. on Earthq. Engin., Paper No. 306.

Fäh D., Ruttener T., Noack T. and Kruspan P. 1997. Microzonation of the City of Basel, Journal of Seismology 1, 87-102.

Field E. 1996. Spectral amplification in a sediment-filled valley exhibiting clear basin-edge induced waves, Bull. Seismol. Soc. Am., 86, 991-1005.

Field E. and Jacob K. 1993. The theoretical response of sedimentary layers to ambient seismic noise, Geophysical Research Letters, 20(24), 2925-2928.

Gosar A. 2007. Microtremor HVSR study for assessing site effects in the Bovec basin (NW Slovenia) related to $1998 \mathrm{M}_{\mathrm{w}} 56$ and $2004 \mathrm{M}_{\mathrm{w}} 52$ earthquakes, Engineering Geology, 91, 178193.

Hatzopoulos J. 2008. Topographic Mapping, Universal Publishers, pp. 208, 290.

Hecht J. 1972. Zur Geologie von Sudost Lesbos (Griechenland), Z. Deutsch Geol.123, 423-432.

Hecht J. 1974a. Geological map of Greece, 1;50000, Mithimna sheet, IGME.

Hecht J. 1974b. Geological map of Greece, 1:50000, Polychnitos sheet, IGME. 
Hloupis G., Vallianatos F. and Stonham J. 2005. A wavelet representation of HVSR technique, Bulletin of the Greek Geological Society, 36(3), 1269-1278.

Seht M. Ibs-von and Wohlenberg J. 1999. Ambient noise Measurements used to map thickness of soft sediments, Bull. Seismol. Soc. Am., 89, 250-259.

Jimenez M. J., Garcia-Fernandez M., Zonno G. and Cella F. 2000. Mapping Soil Effects in Barcelona, Spain, Through an Integrated GIS Environment, Soil Dynamics and Earthquake Engineering, 19, 289-301.

Katsikatsos G., Mataragas D., Migiros G. and Triantaphyllis E. 1982. Geological study of Lesvos Island. IGME (interna report), Athens.

Katsikatsos G. Migiros G., Triantaphyllis M. and Mettos A. 1986. Geological structure of internal Hellenides (E. Thessaly - SW. Macedonia, Euboea - Attica - Northern Cyclades islands and Lesvos, IGME. Geol. \& Geoph. Res. Special Issue, 191-212.

Moisidi M., Vallianatos F., Soupios P. and Kershaw S. 2012. Spatial spectral variations of microtremors and electrical resistivity tomography surveys for fault determination in southwestern Crete, Greece, J. Geophys. Eng. 9, 261-270.

Moisidi M., Vallianatos F., Soupios P., Kershaw S., Rust D. and Piscitelli S. 2013. Modeling tectonic features of the Kissamos and Paleohora areas, Western Crete (Greece): combining geological and geophysical surveys, J. Geophys. Eng., 10025015 doi:10.1088/17422132/10/2/025015.

Mucciarelli M. 1998. Reliability and Applicability of Nakamura's technique using Microtremors: An experimental approach, J. Earthq. Eng., 2, 625-638.

Nakamura Y. 1989. A method for Dynamic Characteristics Estimation of Subsurface using Microtremor on the Ground Surface, Quarterly Report of Railway Technical Research Institute (RTRI), vol. 30, No. 1.

Nakamura Y. 1997. Seismic Vulnerability Indices For Ground and Structures Using Microtremor, World Congress on Railway Research in Florence, Italy, November 1997.

Navarro M., Enomoto T., Sanchez F. J., Matsuda I., Iwatate T., Posadas A. M., Luzon F. and Seo K. 2001. Surface soil effects study using short-period Microtremors observations in Almeria City, Southern Spain, Pure Appl. Geophys., 158, pp. 2481-2497.

Nogoshi M. and Igarashi T. 1971. On the Amplitude Characteristics of Microtremor (Part 2) (in Japanese with English abstract), Jour. Seism. Soc. Japan, 24, pp. 26-40.

Papazachos B. and Papazachou K. 1997. Earthquakes of Greece, Ziti editions (new edition). Thessaloniki, Greece.

Pe-Piper G. and Piper D.J.W. 1993. Revised stratigraphy of the Miocene volcanic rocks of Lesvos, Greece, Neues Jahrbuch Geologie und Palaeontologie Munchen, 2, 97-110.

Pe-Piper G. 1978. Cainozoic Volcanic Rocks of Lesvos Island, Ph.D. Thesis, University of Patras, $365 \mathrm{p}$.

Sarris A., Loupasakis C., Soupios P., Trigkas V., Vallianatos F. 2010. Earthquake vulnerability and seismic risk assessment of urban areas in high seismic regions: application to Chania City, Crete Island, Greece, Nat. Hazards, 54, 395-412.

Soulakellis N., Novak I., Zouros N., Lowman P. and Yates J. 2006. Fusing Landsat-5/TM Imagery and Shaded Relief maps in Tectonic and Geomorphic Mapping: Lesvos Island, Greece, Photogrammetric Engineering and Remote Sensing,72(6), 693-700.

Woolery E. W. and Street R. 2002. 3D near-surface soil response from H/V ambient-noise ratios, Soil Dyn. Earthq. Eng., 22, 865-876.

Vallianatos F. and Hloupis G. 2008. HVSR Technique Improvement Using Redundant Wavelet Transform in Increasing Seismic Safety by Combining Engineering Technologies and Seismological Data, NATO Science for Peace and Security Series C: Environmental Security ISSN1874-6519, Spinger Netherlands.

Yamanaka H., Takemura M., Ishida H. and Niwa M. 1994. Characteristics of Long-Period microtremors and their applicability in exploration of deep sediments, Bull. Seismol. Soc. Am., 84, 1831-1841. 